\title{
The Relationship of Work Stress, Emotional Intelligence, and The Performance of Staff in the Office of the Ministry of Religion Batam City Indonesia
}

\author{
Hazriyanto $^{1}$, Indra Firdiyansyah ${ }^{2}$, Syed Sofian Syed Salim ${ }^{3}$ \\ ${ }^{1,2}$ Faculty of Economics and Management, STIE Galileo, Batam, Indonesia \\ ${ }^{3}$ Faculty of Human Development, Sultan Idris Education University, Tanjong Malim, Perak, \\ Malaysia \\ 1'hazriyanto@gmail.com, ${ }^{2}$ indrafirdiyan@gmail.com, ${ }^{3}$ sofian@fpm.upsi.edu.my
}

\begin{abstract}
Issues that generally are facing is how human can create resources capable of generating optimal performance so that the objectives of the organization can be achieved. Many factors can affect the performance of the person who will ultimately be able to realize the achievement of organizational performance. Problem in the work stress, emotional intelligence, and performance becomes important to be noted. The variables examined in this study are work stress, emotional intelligence, and the performance of staff in the Office of the Ministry of Religion, Batam city, Indonesia. The data collection tool in research were using questionnaires and analyzed with SPSS statistics tools. This assessment involved 13 items of work stress, 28 items of emotional intelligence, and 6 items of performance.Populations and samples in this study was 33 staff as respondent. The acquired results of the research showed that the stress of work and the performance has a negative and significant relationship, emotional intelligence and performance had a positive and significant relationship, whereas stress work and emotional intelligence competencies the negative was not significant. upcoming research suggested to examine the demographic and other variables which were not examined in this study such as; commitment, and job satisfaction.
\end{abstract}

Keywords: Work Stress, Emotional Intelligence, Performance of Staff.

\section{Introduction}

Human resource development should be seen as part of the Organization's purposes, the community, and not simply the interests of the State. The staff should've been able to improve the quality of service and resolve problems encountered, either individually or in a group. Need to be aware that the involvement of staff in the Office of the Ministry of Religion Batam city in terms of providing public servants should be included starting from the process of planning, implementation, evaluation, and utilization of results. Staff are expected to achieve a performance that is one of the essential components in a system of public service in the Office of the Ministry of Religion Batam city.

There are many factors that contribute to the achievement of the performance of the staff such as work stress, emotional intelligence, job satisfaction, etc. Emotional intelligence is the driving 
factor in the success of an employee of an organization. Whereas work stress also participated in determining the level of performance of employees. Based on the description, the authors are interested in conducting research with the title "work stress, emotional intelligence, and the performance of Staff in the Ministry of Religion Batam city".

This research is limited to the stage of work stress, the emotional capabilities, and performance of the staff. Formulation of the problem are;

1. Is there a relationship of work stress with the performance of staff in the Ministry of Religion Batam city?

2. Is there a relationship of emotional intelligence with the performance of staff in the Ministry of Religion Batam city?

3. Is there a relationship of work stress with emotional intelligence staff in the Ministry of Religion Batam city?

The purpose of this research is;

1. To know the relationship between work stress with the performance of staff in the Ministry of Religion Batam city.

2. To know the relationship between emotional intelligence with the performance of staff in the Ministry of Religion Batam city.

3. To know the relationship of stress of working with emotional intelligence staff in the Ministry of Religion Batam city.

According to Robbins [1]performance is the result or the person's overall success rate during a certain period in carrying out the task compared to a range of possibilities, such as the standard work, targets/goals or criteria.

The performance is a process about how the work underway to achieve results work [2]According to Looker, Terry \& Gregson, Olga [3]stress is defined as the status when it shows up in the mismatch between the demands with capabilities. Sebaradar, Shabnam. \&Asadi, Hameidah [4]described that emotional intelligence plays a vital role in the professional life and it is very helpful in the achievement of career success.

Measurement of work stress, emotional intelligence, and the performance of the staff of the Ministry of religion based on staff perception of Batam city is done by evaluating the item of work stress, emotional intelligence, and performance in accordance with the relevant literature references Adaptation/Adoopsi [5]

Research conducted by the Yozgat et al.,[5]results showed a negative relationship was found between job stress and job performance, emotional intelligence had a positive impact on job performance.

\section{Research Methods}

In a study, one of the things that's important is devising a research design. Type of this research is quantitative descriptive research. The research was conducted at the Office of the Ministry of Religion Batam city which is located in JL. Baiturrahman mosque in Sekupang Batam.The Census technique with the overall member population as a sample was used.The sample in this research were 33 respondents from the staff in the Office of the Ministry of Religion Batam city. So in this study population was a sample, consisting of staff of the Office in the Ministry of Religion Batam city. All staff participated voluntarily in filling the questionnaire which had been briefed about the purpose of the research provided by the researchers. The variable in this study were work stress, emotional intelligence, and performance.

Item instrument of work stress, emotional intelligence, and performance in this study is an adaptation/adoption of [5]

Work stress has 13 items namely; 
1. Working here makes it hard to spend enough time with my family

2. I spend so much time at work; the trees??

3. Working here leaves little time for other activities.

4. I frequently get the feeling I am married to the company

5. I have too much work and too little time to do it in.

6. I sometimes dread the telephone ringing at home because the call might be job-related

7. I feel like I never have a day off

8. Too many people at my level in the company get burned out by job demands

9. I have felt fidgety or nervous as a result of my job

10. My job gets me more than it should

11. There are lots of times when my job drives me right up the wall

12. Sometimes when I think about my job I get a tight feeling in my chest.

13. I feel guilty when I take time off from job

Emotional intelligence there are 28 items namely;

1. When I am facing with obstacles, I remember times I faced similar obstacles and overcame them.

2. I expect that I will do well on must things I try.

3. Other people find it easy to confide in me

4. Some of the major events of my life have led me to reevaluate what is important and not important

5. When my mood changes, I see new possibilities.

6. Emotions are one of the things that make my life worth living

7. I am aware of my emotions as I experience them.

8. I expect good thing to happen.

9. I like to share my emotions with others.

10. When I experience a positive emotion, I know how to make it last

11. I arrange events that others enjoy

12. I seek out activities that make me happy

13. I am aware of non-verbal messages that I send to others.

14. I present myself in a way that makes a good impression on others

15. When I am in a positive mood, solving problems is easy for me

16. By looking at their facial expressions, I recognize the emotions people are experiencing.

17. I know why my emotions change.

18. When I am in a positive mood, I am able to come up with new ideas.

19. I easily recognize my emotions as I experience them.

20. I motivate myself by imaging a good outcome to tasks I take on.

21. I compliment others when they have done something well.

22. I am aware of non-verbal messages that other people send.

23. When another person tells me about an importance event in his or her life, I almost feel as though I have experienced this event myself.

24. I know what other people are feeling just by looking at them.

25. I help other people feel better when they are down.

26. I use good moods to help myself keep trying in the faceoff obstacles

27. I can tell how people are feeling by listening to the tone of their voice

28. It is difficult for me to understand why people feel the way they do

Whereas, the performance consists of 6 items namely; 
1. How would you rate yourself in terms of the quantity of work you achieve?

2. How do you rate yourself in terms of your ability to reach your goals?

3. How do you rate yourself in terms of your performance potential among coworkers in your company?

4. How do you rate yourself in terms of quality of your performance in regard to customer relations?

5. How do you rate yourself in terms of quality of your performance in regard to management of time, planning ability, and management of expenses?

6. How do you rate yourself in terms of quality of your performance in regard to knowledge of your products, company, competitors' products, and customer needs?

A quantitative approach is used in this research. The data obtained by using a questionnaire developed by researchers with the respondent is the staff in the Office of the Ministry of Religion Batam city. The instrument used was a questionnaire consisting of 47 items. Items used is an item of work stress, emotional intelligence, and performance.

The source of the data used in the research is primary data, and data collected by researchers from the object of research.Primary data collection was done by way of survey method by distributing questionnaires to respondents. A questionnaire distributed to staff in the Office of the respondent's Ministry of Religion Batam city. Respondents gave answers on every item with the given five choices of answers. Answers of the respondents viewed from the trend are the answers of respondents tend to move to the left-most columns or to the right-most column, which dispute the work stress, emotional ability, and good or bad performance of each item.Here is a picture of the model of research;

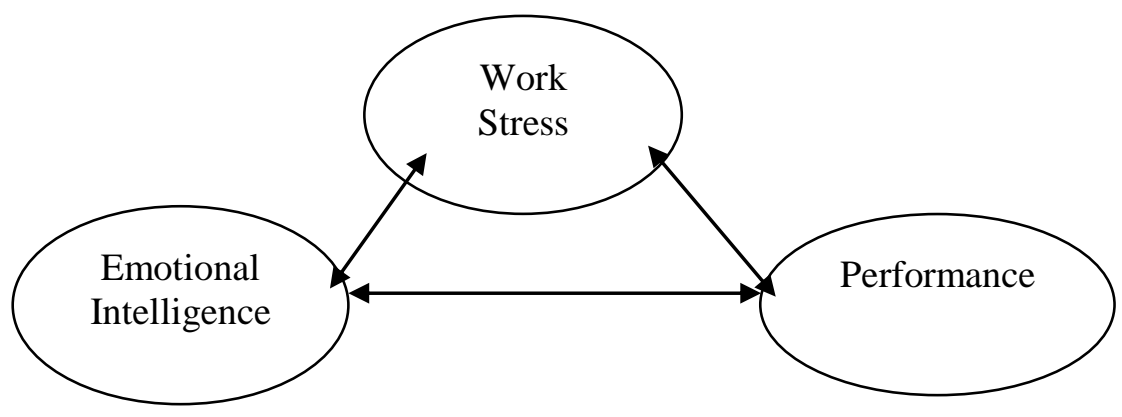

Fig. 1. Work stress, emotional intelligence, and performance

Data analysis for testing was using a descriptive analysis of correlation factors with work stress, emotional intelligence, and performance.These measurements are selected because of the awareness of researchers to the nature of the appraiser's differences when evaluating staff.Analysis of the data used in this study was to find out the quantity and percentage of demographic characteristics of the respondents, also a correlation between variables. Data analysis in this research was is a descriptive statistic and correlations. Demographics of respondents in this study in terms of the gender of the respondent.

\section{Results and Discussion}

The data of the respondents in the study can be seen in the following table: 
Table 1: Respondent Data

\begin{tabular}{|c|c|}
\hline Gender & The Total Number \\
\hline Man & 12 \\
Women & 21 \\
\hline Total & 32 \\
\hline
\end{tabular}

Table 1 shows that the number of respondents in the study consisted of 12 men and 21 women of 33 respondents.In order to describe the research variables, certain criteria based on the average score obtained the now respondent categories are used.The score in accordance with the five categories score Likert scale developed and used in the study. As for the criterion in question as propounded by Abdurahman [6] shown in table 2 below:

Table 2: Criteria Analysis Description

\begin{tabular}{|l|l|}
\hline The Range Of Category Score & The interpretation \\
\hline $1.00-1.79$ & Not Very Good/Very Low \\
$1.80-2.59$ & Not Good/Low \\
$2.60-3.39$ & Enough/Average \\
$3.40-4.19$ & Good/High \\
$4.20-5.00$ & Very Good/Very High \\
\hline
\end{tabular}

The following research results analysis mean score of respondents against the variables examined, as shown in the following table:

Table 3: Descriptive Analysis

\begin{tabular}{|l|l|l|}
\hline Variable & Mean Score & Description \\
\hline Work Stress & 2.62 & Enough \\
\hline Emotional Intelligence & 3.73 & Good \\
\hline Performance & 3.70 & Good \\
\hline Total Mean Score & 3.35 & Enough \\
\hline
\end{tabular}

A descriptive analysis of the results of menscore to work stress variables (2.62), emotional intelligence (3.73), and performance (3.70) and mean score overall of 3.35 was on stage enough.Furthermore, The validity results of the items can be seen in the following table:

Table 4: Results of Test validity of work stress

\begin{tabular}{|l|l|l|}
\hline \multicolumn{2}{|l|}{ Item-Total Statistics } & \\
\hline Item & r_statistics> r_table $(0,349)$ & Description \\
\hline SK1 &, 627 & Valid \\
\hline SK2 &, 655 & Valid \\
\hline SK3 &, 681 & Valid \\
\hline SK7 &, 650 & Valid \\
\hline SK8 &, 551 & Valid \\
\hline SK9 &, 376 & Valid \\
\hline SK12 &, 653 & Valid \\
\hline
\end{tabular}

Test the validity of the 32 respondents by using SPSS program version 20.0 obtained test results validity against the 13 items and only 7 items in the questionnaire statements have a value 
of r-statistics (Corrected Item-Total Correlation) above 0.349 , thus There are 7 items a valid statement.

Table 5: Results of Test Validity of Emotional Intelligence

\begin{tabular}{|l|l|l|}
\hline \multicolumn{2}{|l|}{ Item-Total Statistics } \\
\hline Item & r_statistics > r_table $(0,349)$ & Description \\
\hline KE2 &, 562 & Valid \\
\hline KE3 &, 476 & Valid \\
\hline KE4 &, 589 & Valid \\
\hline KE5 &, 470 & Valid \\
\hline KE8 &, 603 & Valid \\
\hline KE9 &, 644 & Valid \\
\hline KE10 &, 678 & Valid \\
\hline KE12 &, 683 & Valid \\
\hline KE14 &, 455 & Valid \\
\hline KE15 &, 599 & Valid \\
\hline KE16 &, 539 & Valid \\
\hline KE17 &, 508 & Valid \\
\hline KE18 &, 564 & Valid \\
\hline KE19 &, 615 & Valid \\
\hline KE20 &, 747 & Valid \\
\hline KE21 &, 725 & Valid \\
\hline KE22 &, 458 & Valid \\
\hline KE23 &, 612 & Valid \\
\hline KE26 &, 631 & Valid \\
\hline KE27 &, 477 & Valid \\
\hline
\end{tabular}

Test the validity of the results of the questionnaire respondents 33 using SPSS program version 20.0 obtained test results validity against the 28 -item statement. 20 item statements in questionnaires that have a value of r-statistics (Corrected Item Total Correlation) above 0.349 thus Revelation 20 items are valid.

Table 6: Results of Test Validity of Performance

\begin{tabular}{|l|l|l|}
\hline \multicolumn{2}{|l|}{ Item-Total Statistics } \\
\hline Item & r_statistics > r_table $(0,349)$ & Description \\
\hline KIN1 &, 717 & Valid \\
\hline KIN2 &, 583 & Valid \\
\hline KIN3 &, 805 & Valid \\
\hline KIN4 &, 751 & Valid \\
\hline KIN5 &, 817 & Valid \\
\hline KIN6 &, 830 & Valid \\
\hline
\end{tabular}

The results of validity test on the questionnaire with respondents 33 was obtained by using SPSS program version 20.0.The results validity test against 6 statement in the questionnaire that each have a value of r-statistics (Corrected Item-Total Correlation) is above 0.349.Thus all statements is valid. 
Table 7: Reliability test results of work stress, emotional intelligence, and performance

\begin{tabular}{|l|l|l|}
\hline Reliability Statistics & Cronbach's Alpha & Reliability \\
\hline Variable & 0,844 & Reliability \\
\hline Work Stress & 0,919 & Reliability \\
\hline Emotional Intelligence & 0,909 & Reliability \\
\hline Performance &
\end{tabular}

Table 7 retrieved values of Alpha Chronbach's 0.844, 0.919, 0.909 (greater than 0.70), then the device of this questionnaire can be trusted and reliable (reliability).

Table 9: Normality test results

One-Sample Kolmogorov-Smirnov Test

\begin{tabular}{|ll|l|}
\hline & & $\begin{array}{l}\text { Standardized } \\
\text { Residual }\end{array}$ \\
\hline $\mathrm{N}$ & & 33 \\
Normal Parameters ${ }^{\mathrm{a}, \mathrm{b}}$ & Mean &, 0000000 \\
& Std. Deviation &, 96824584 \\
Most Extreme Differences & Absolute &, 160 \\
& Positive &, 160 \\
Test Statistic & Negative &,- 088 \\
Asymp. Sig. (2-tailed) & &, 160 \\
\hline
\end{tabular}

Table 9 shows the test result that the value of Asymp normality. Sig. (2-tailed) value is 0.032 and brought significant (0.05) thus the data distribution is not normal. For the next process because the data distribution is not normal then a non parametric test is performed to measure the relationship between the variables. Correlation of test results as shown in the following table:

Correlations

Table 10: Non parametric Correlation test results

\begin{tabular}{|c|c|c|c|c|}
\hline & & & Work Stress & $\begin{array}{l}\text { Emotional } \\
\text { Intelligence }\end{array}$ \\
\hline \multirow[t]{9}{*}{ Kendall's tau_b } & \multirow[t]{3}{*}{ Work Stress } & Correlation Coefficient & 1,000 &,- 016 \\
\hline & & Sig. (2-tailed) & & ,900 \\
\hline & & $\mathrm{N}$ & 33 & 33 \\
\hline & \multirow{3}{*}{$\begin{array}{l}\text { Emotional } \\
\text { Intelligence }\end{array}$} & Correlation Coefficient &,- 016 & 1,000 \\
\hline & & Sig. (2-tailed) & ,900 & \\
\hline & & $\mathrm{N}$ & 33 & 33 \\
\hline & \multirow[t]{3}{*}{ Performance } & Correlation Coefficient &,- 253 &, $291^{*}$ \\
\hline & & Sig. (2-tailed) & 055 & ,027 \\
\hline & & $\mathrm{N}$ & 33 & 33 \\
\hline \multirow[t]{4}{*}{ Spearman's rho } & \multirow[t]{3}{*}{ Work Stress } & Correlation Coefficient & 1,000 & ,019 \\
\hline & & Sig. (2-tailed) & $\cdot$ & ,918 \\
\hline & & $\mathrm{N}$ & 33 & 33 \\
\hline & Emotional & Correlation Coefficient & ,019 & 1,000 \\
\hline
\end{tabular}




\begin{tabular}{|ll|l|l|} 
Intelligence & Sig. (2-tailed) &, 918 &. \\
& $\mathrm{~N}$ & 33 & 33 \\
\cline { 2 - 5 } Performance & Correlation Coefficient &,$- 347^{*}$ &, $443^{* *}$ \\
& Sig. (2-tailed) &, 048 &, 010 \\
& $\mathrm{~N}$ & 33 & 33 \\
\hline
\end{tabular}

Exam results correlation test nonparametrik table 10 shows that the relationship between work stress and emotional intelligence (0.019) are on very weak category, work stress with performance $(-0.347)$ are on a weak category, and emosiional intelligence with performance $(0.443)$ are on a weak category [7]The relationship of work stress and performance, emotional intelligence and performance significantly. Work stress and emotional intelligence are not significant. The results of this research are consistent with research done [5]

\section{Conclusion}

The relationship of work stress and performance. There was a weak negative relationships and significant between work stress and performance. The relationship of emotional intelligence and performance. There was a weak positive relationship and significant between emotional intelligence and performance. The relationship of work stress and emotional intelligence. There were relations which are very weak and insignificant between work stress and emotional intelligence. These relationships need to be constantly maintained and given the attention that there are relationships between the variables in question.For the next research other variables Besides work stress, emotional intelligence, and performance such as motivation and commitment is required to be examined.In addition, it is recommended to study with a larger sample size and statistical tools such as; Amos, SmartPLS, etc.

\section{sAcknowledgement}

Thanks to Prof. Madya. Dr.Syed Sofian Syed (Salim UPSI Lecturer), Dr. Eng. Ansarullah Lawi (Universal University Lecturer), Indra Firdiyansyah (STIE Galileo Lecturer), M. Yahmin (Chairman of STIE Galileo) and other colleagues at STIE Galileo.

\section{REFERENCE}

[1] S. P. Robbins, PrilakuOrganisasi. Ahli bahasa: HandayanaPujaatmaka. Jakarta: Prenhallindo, 2006.

[2] Wibowo, Manajemen Kinerja, 3rd ed. Jakarta: Rajawal Pers, 2011.

[3] B. T. Gregory, S. G. Harris, A. A. Armenakis, and C. L. Shook, "Organizational culture and effectiveness: a study of values, attitudes, and organizational outcomes," J. Bus. Res, vol. 62, no. 7, pp. 673-679, 2009.

[4] S. \&Asad. Sebaradar and H., "Emotional intelligence and job satisfaction in Ardabil educational organization," in Vol.3, No.4, 25222529, ISSN, 2013, pp. 2249-7196.

[5] U. Yozgat, S. Yurtkoru, and E. Bilginoglu, "Job stress and job performance among employees in public sector in Istanbul: examining the moderating role of emotional intelligence," Procedia - Social and Behavioral Sciences, vol. 75, no. 2013, pp. 518-524, 2013.

[6] S. A. Muhidin and M. Abdurrahman, Analisis Korelasi, Regresi, dan Jalur dalam Penelitian, 1st ed. Bandung: CV PUSTAKA SETIA, 2009.

[7] Y. P. Chua, Uji Regresi, Analisis Faktor dan analisis SEM: kaedah dan Statistik Penyelidikan (Kedua). Malaysia: McGraw-Hill Education, 2014. 
